\title{
Accounting
}

\section{How to improve financial performance of tourism and travel enterprises: The case of Vietnam}

\author{
Thi Lua Pham ${ }^{\mathrm{a}}$ and Thi Thu Hien Phan ${ }^{\mathrm{a}}$
}

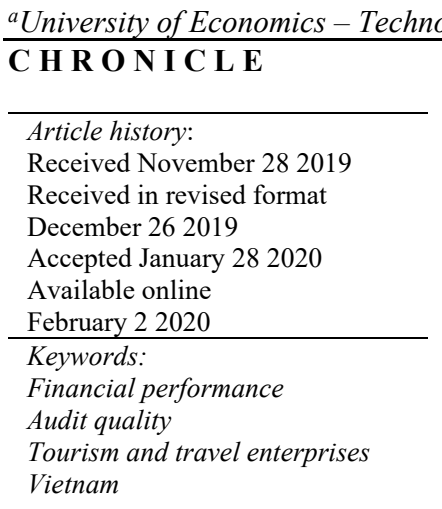
\begin{abstract}
A B S T R A C T
The objective of this paper is to study how to improve the financial performance of Vietnamese tourism and travel enterprises through audit tools. The study was conducted on 228 tourism and travel enterprises in Vietnam over a period of 1 year. The results show that quality of audit could improve the financial performance of tourism and travel enterprises in Vietnam. This relationship, however, was not a full mediate relationship, but audit quality still had a strong impact on capital access, customer loyalty, employee satisfaction and corporate reputation. Nevertheless, the two mediate factors that access capital and employee satisfaction did not have any statistically significant impact on financial performance.
\end{abstract}

\section{Introduction}

(C) 2020 by the authors; licensee Growing Science, Canada

In recent decades, the world has witnessed the growth of the tourism industry, becoming one of the world's largest industries, and making a positive contribution to economic development. As the international tourism market grows, the competitiveness of the destination is considered an important factor affecting tourism business activities. Pearce et al. (1997) argue that as world travel becomes more and more competitive, all the profound perception of the destination's development, strengths and weaknesses will be of paramount importance. Ritchie and Crouch (2000) emphasize that the competitiveness of a destination has an internal classification effect and therefore (competitiveness) is a matter of particular interest for businesses and policymakers. For tourism destinations, competitiveness is just considered as a driving force and development goal of the destination, because competitiveness will increase the opportunity to attract tourist markets, promote tourism development leading to the development of auxiliary industries, promoting socio-economic development of the destination localities and contributing to poverty reduction. Vietnamese businesses in general and tourism and tourism businesses in particular have different competing strategies including the one that is important to improve the quality of published media. One of the important information that is published is whether the financial statements are reliable or not. The quality of information on financial statements depends on the quality of the audit. Audit quality greatly affects the performance of enterprises through various forms, which can directly or indirectly affect intermediary variables. In order to promote the development of Vietnamese enterprises in general and tourism enterprises in particular, many policies and plans have been proposed. However, with the desire to improve the quality of internal audit as well as independent audit, so this article focuses on studying the impact of audit quality on the financial performance of tourism businesses, Vietnamese calendar and travel.

* Corresponding author.

E-mail address: ptthien.kt@uneti.edu.vn (T.T.H. Phan)

(C) 2020 by the authors; licensee Growing Science, Canada doi: $10.5267 /$ j.ac.2020.2.001 
The structure of the article in addition to the introduction includes: Overview of research, research methods, research results and conclusions.

\section{Literature review}

\subsection{Researches on financial activities, quality of financial activities, financial performance}

Financial activities are one of the basic contents of business activities of enterprises in order to solve economic relations arising in the business process expressed in the form of currency to realize the objectives of enterprises profit maximization or equity maximization. In other words, financial activities are monetary relations directly associated with the organization, mobilization, distribution and use of capital management in the business process. The quality of financial activities is reflected in whether financial activities are effective or not. Currently, there are a number of studies on financial performance and the quality of financial activities. The quality of financial activities is determined by the financial performance of an enterprise in which the concept of financial performance is represented. For example, Almajali et al. (2012) argue that there are many ways to measure the financial performance, for example, sales revenue shows how much money a company earns in relationship with sales and profits on assets explaining usability. Company assets and return on equity show the return on investment of investors. The financial performance of a company can be assessed in three aspects: The first aspect is the firm's productivity, or the efficient processing of inputs into outputs; The second is the profit aspect, either the company's level of income is greater than its cost and the third is the market premium, or the company's market value in excess of book value (Walker \& Tsalta, 2001). Chen and Wong (2004) performed an investigation on the determinants of financial health of Asian insurance companies measure accounting profits using Return on Assets (ROA). They pointed out ROA could be widely used by market analysts as a measure of financial performance because it could evaluate the effectiveness of assets in generating income. The most commonly used accounting measures are ROA (McGuire et al., 1988; Russo \& Fouts, 1997, Stanwick and Stanwick, 2000, Clarkson et al., 2008), Return of Equity (ROE) (Bowman and Haire, 1975), and Return on Sales (ROS) (Stanwick \& Stanwick, 1998). Therefore, the study uses return on assets (ROA) and return on equity (ROE) as a measure of financial efficiency and financial performance.

\subsection{The research on audit and the factors affecting the quality of audit}

Auditing is considered as one of the effective tools in controlling and improving the financial performance of enterprises. Effective control that contributes to improving the quality of financial operations depends greatly on the quality of the audit. Therefore, the study of audit quality will propose solutions to improve the quality of financial activities through audit tools. Audit quality is subject to research that has been studied since the early 1980s in various countries such as the US (e.g. DeAngelo 1981; Francis, 1984; Francis \& Simon 1986), Australia (e.g. Craswell et al., 1995), UK (e.g. Che Ahmad \& Houghton 1996), Hong Kong (e.g. Gul, 2013), and Malaysia (e.g. Mohd-Mohid \& Takiah 2004). In a study conducted among members of the Malaysian Accounting Academy (MIA) in 1990, survey respondents considered auditing quality as one of the most important issues in this industry (Teoh, 1990). The quality of the audit is usually tied to the quality of the financial statements. Evidence shows that the quality of audits varies due to factors such as firm size, areas of expertise, office characteristics and cross-border differences in the legal system and level of responsibility of auditors (Francis, 2004). A study in Malaysia showed that the size of auditing firms has a significantly positive relationship with the quality of financial statements (e.g. Lily Marlina \& Takiah 2003). The financial statements sent by the Board of Directors to related parties need to be corroborated by external auditors. The endorsement by an external entity, independent of the person preparing the report, gives financial statements certain reliability. The financial statements are expected to be free from material misstatements if the auditor provides quality assurance. This is consistent with De Angelo (1981), who defined audit quality as the probability that a material misstatement of financial statements could be detected and reported by the auditor. This indicates the importance of the auditor's competence and independence in determining the quality of the audit. Both factors regarding the quality of the audit, independence and competence, relate to the characteristics of the auditor. Given the above-mentioned characteristics, auditors may perform their role in minimizing information gaps between management and related parties in order to provide a guarantee that financial statements. There are no major flaws in general. High quality external audit plays an important role in corporate governance to improve reporting quality. It enhances the reliability of financial statements and the confidence of users with those reports. The importance of high audit quality for improved control and management processes is recognized by the Cadbury Commission. It helps minimize capital costs through minimizing information risks. As a result, high quality independent audits improve the company's monitoring and control mechanism (Khurana \& Raman 2004). As a monitoring mechanism, auditing is used by companies to reduce agency costs from lenders and related parties (Jensen \& Meckling 1976; Watts \& Zimmerman 1983). In addition, the audit reduces the difference in net income and net assets in the financial statements after the audit (Kinney \& Martin 1994). Therefore, the audit improves the allocation of resources in the capital market through an effective decision-making process.

\subsection{Audit quality and financial performance}


There are several studies that demonstrate that the quality of an audit helps improve a company's financial performance. Afza and Nasir (2014) mentioned that independent audit quality helps to improve the performance of the company from the perspective of investors. They realize that companies audited by large audit firms will disclose reliable, relevant and authentic financial statements, which will help to strengthen investor confidence in general for investors. this company. Furthermore, Jusoh et al. (2013) suggested that high quality audits can reduce agency costs when the auditor provides an indicator of the reliability and completeness of financial statements, from which can lead to reduced monitoring costs and help the company to be more effective. Similarly, Fooladi and Shukor (2012), and Farouk and Hassan (2014), reported a positive relationship between audit quality and firm performance. Therefore, audit quality is expected to have a positive relationship with financial performance.

\section{Credit theory}

This theory shows that the main function of an audit is to add credibility to the financial statements. The reliability of users is increased when based on audited financial statements instead of financial statements presented by management. Therefore, management uses audited financial statements to enhance the confidence of stakeholders in their management activities. Users are considered to benefit from increasing trust, these benefits are often considered, the quality of investment decisions is improved based on reliable information (Hayes et al. 2005). Audited financial statements enhance the main agency relationship and reduce information asymmetry. Akinbuli (2010) stated that audited financial statements can enhance the confidence of stakeholders in management. This means that companies with audit reports of quality assurance, reliability, investors, credit will easily invest and lend the company more capital.

\section{Police theory}

According to this theory, an auditor acts as a police officer to ensure the accuracy and ability to prevent and detect fraud. This theory makes auditors detect and prevent fraud and fraud in organizations. Business administrators should establish and maintain strong internal control systems to enhance prevention, fraud detection and any other anomalies in the organization. The auditor is not responsible for seeking fraud unless he has entered into a specific agreement with the audited company management to do so. However, if the audit is done in accordance with the process, the work of the auditor will detect fraud of the audited enterprise. The main focus of the auditor is to verify the integrity of the financial statements and provide reasonable assurance. However, fraud detection is still a hot topic in the debate about auditors' responsibilities and often after financial reporting fraud events are discovered and pressures increase liability. of auditors in detecting fraud (Hayes et al, 2005).

Based on the above analysis, the authors put forward the following research hypotheses:

H1: Good audit quality has a positive impact on customer loyalty.

$\mathbf{H}_{2}$ : Good audit quality has a positive impact on employee satisfaction.

$\mathbf{H}_{3}$ : Good audit quality has a positive impact on the Reputation of Enterprises.

$\mathbf{H}_{4}$ : Good audit quality has a positive impact on enterprises' capital access.

H5: Good audit quality has a positive impact on the financial performance of businesses.

H6: Customer loyalty has a positive impact on the financial performance of businesses.

$\mathbf{H}_{7}$ : Employee satisfaction has a positive impact on financial performance.

H8: Reputation of businesses has a positive impact on financial performance.

H9: The ability of enterprises to access capital has a positive impact on financial efficiency.

$\mathbf{H}_{\mathbf{1 0}}$ : Reputation, access to capital, customer loyalty and employee satisfaction play an intermediary role in the relationship between audit quality and financial performance of businesses.

\section{Research method}

\subsection{Research sample}

Total number of questionnaires issued by the project team was 256, with 242 businesses responding. On the basis of collected data, the study processed to synthesize, classify, select and summarize to use the data of 228 votes for the quantitative survey process and there were 33 large-scale enterprises, 86 medium-sized enterprises and 123 small-scale enterprises (See Fig. 1). 


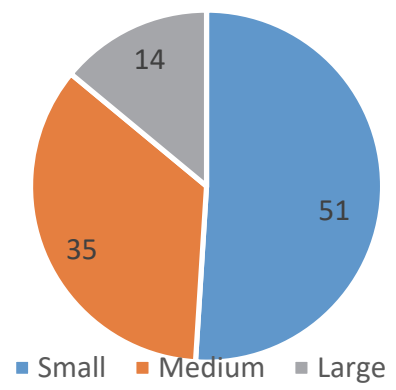

Fig. 1. Classification of surveyed enterprises by size

\subsection{Research methodology and research model}

In order to accomplish the research objectives, we used quantitative and qualitative methods in the research. The qualitative research method is used to describe and analyze the business characteristics of the SOEs in the RRD that affect the TC activities. The qualitative method is done through collecting data in the form of documents and decisions (word data), from which to approach the research object in order to find ways to describe and analyze the characteristics of the research object. The quantitative research method is used as follows: on the basis of analyzing and synthesizing information from domestic available data on contents related to the research subjects, subjects of collection and distribution.

The research model is as follows:

Inside:

- The quality of the audit / reliability of the financial statements is measured through 5 aspects: the size of the auditing firm, the auditor's independence, the auditor's expert presentation, the cost of the audit team and the auditor's experience and the effectiveness and efficiency of the internal audit department developed adopted from Phan et al. (2020).

- Non-financial efficiency includes 4 aspects development from the research of Aras et al. (2010).

- Financial performance is the last potential variable - the dependent variable of the research model is measured through two aspects: profitability and growth developed from the research of Santos and Bristo (2012).

Potential variables and scales include:

- Auditing firm size:

Auditing firm size affects the quality of the audit.

The audit firm's network affects the quality of its audit.

The number of partners of audit firms affects the quality of the audit.

- Independence of auditors

The more independent the auditor is, the higher the quality of the audit.

Independent auditors are always circulated in audits.

Independent auditors are always tested on other economic relationships with the business.

- Auditing experience

The qualifications of audit partners that affect the audit quality of the reported financial results.

Membership for professional organizations has an impact on the audited quality of reported financial results.

The number of qualified auditors that affect the quality of financial statements being reported.

Auditing firms have extensive industry experience that affects the quality of the audit.

The number of experienced auditors in the group will affect the quality of the audit. 
The auditor's international experience affects the quality of the audit.

- Auditing fee:

The higher the audit fee, the higher the quality of the audit.

The audit fee price is in line with the enterprise's expectation.

The audit fee price is consistent with the general market price and the quality of the audit.

- Financial performance:

Measured through two aspects: profitability and growth rate developed from the research of Santos and Bristo (2012).

- Non-financial efficiency

Non-financial effectiveness of the organization includes 4 variables: Customer loyalty, employee satisfaction, access to capital and reputation of businesses. These observed variables are based on a scale of Deshpande and Jones (2001) and Michelman et al. (2011). The observed variables of this scale were measured by a 5-point Likert scale.

+ Loyal customers (customer loyalty)

How often do you measure and assess customer service?

How do you develop products and services based on adequate market and customer information?

The interests of our customers are always our top priority for your company

You believe that your company exists primarily to serve customers

+ Staff satisfied

You are very proud to tell others you are working at this company

You will introduce people to your company with kind words

The company's leadership team is competent and committed to addressing the challenges that the company faces

You are trusted to make meaningful decisions in daily activities.

You are satisfied with the salary the company has paid.

+ Reputation

Customers appreciate the reputation of businesses.

Customers evaluate businesses as successful.

Customer reviews the enterprise as a professional organization.

Customers evaluate businesses as well performing audit activities.

Customers evaluate businesses as a sustainable organization.

-Access to capital

Easy to get loans from banks and other organizations.

Easy to get investment capital from investors.

Activities of improving the quality of auditing help to access capital from credit institutions and investors.

- Internal audit

The administrator said that Internal Audit is an effective tool to support management activities, indispensable in the operations of businesses.

The Internal Audit Department is suitable for the specific conditions of the enterprise. 
The Internal Audit Department must meet a certain number of standards: professional qualifications, personal qualities, professional ethics, etc.

The benefits brought about by IA are always greater than the cost to perform the audit.

Internal audit is organized to ensure effective risk management department, effective risk management models, processes and control systems.

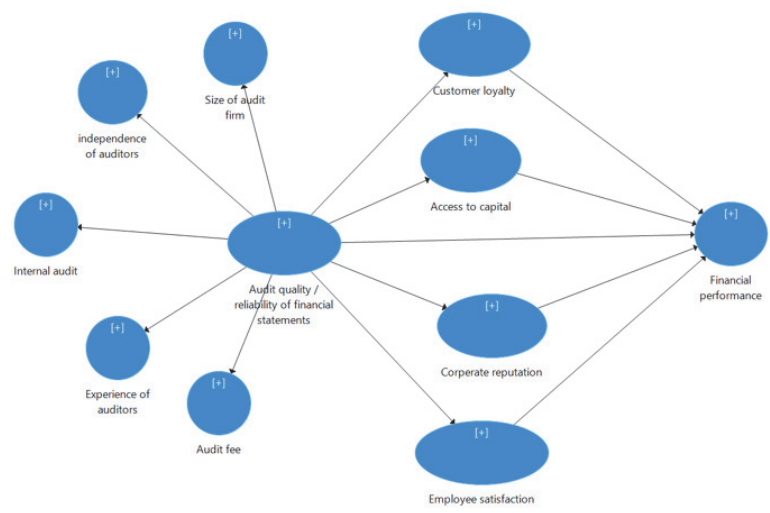

Fig. 2. Research model

\subsection{Data analysis method}

The process of data collection includes tasks such as: Data validation, data editing, spreadsheet creation, identification and calculation of data characteristics, data entry into computers and we use suitable software for processing and analyzing data to meet research objectives. Specifically, to process the primary data collected, the authors used software such as Google Docs, SPSS 22 software, Smart PLS 3.0 and Microsoft Excel. In addition, the study also used other professional technical analysis methods such as comparison, comparison, synthesis, evaluation and expert methods to judge appropriately with dialectical thinking and history.

\section{Research results}

The results of the reliability test of the scale show that all scales meet the conditions. The results of the general reliability testing of scales are as follows:

Table 1

Construct Reliability and Validity

\begin{tabular}{lcccc}
\hline & $\begin{array}{c}\text { Cronbach's } \\
\text { Alpha }\end{array}$ & rho_A & $\begin{array}{c}\text { Composite } \\
\text { Reliability }\end{array}$ & $\begin{array}{c}\text { Average Variance } \\
\text { Extracted (AVE) }\end{array}$ \\
\hline Access to capital & 0.923 & 0.931 & 0.925 & 0.805 \\
Audit fee & 0.887 & 0.887 & 0.887 & 0.662 \\
Audit quality / reliability of financial statements & 0.949 & 0.968 & 0.956 & 0.591 \\
Corporate reputation & 0.920 & 0.920 & 0.920 & 0.697 \\
Customer loyalty & 0.945 & 0.947 & 0.944 & 0.773 \\
Employee satisfaction & 0.838 & 0.840 & 0.838 & 0.634 \\
Experience of auditors & 0.911 & 0.912 & 0.911 & 0.673 \\
Financial performance & 0.949 & 0.950 & 0.949 & 0.650 \\
Internal audit & 0.898 & 0.898 & 0.898 & 0.638 \\
Size of audit firm & 0.872 & 0.873 & 0.872 & 0.694 \\
independence of auditors & 0.910 & 0.911 & 0.910 & 0.629 \\
\hline
\end{tabular}

From the results in Table 1, all the measurement scales satisfy the conditions of analyzing the reliability of the scales and are satisfied to perform the next analysis. From the results in Table 2, the potential variables satisfy the discriminatory condition and are eligible to test the research hypotheses. The results of testing the conformity of the model are given in Table 3 . 
Table 2

Discriminant Validity (Fornell-Larcker Criterion)

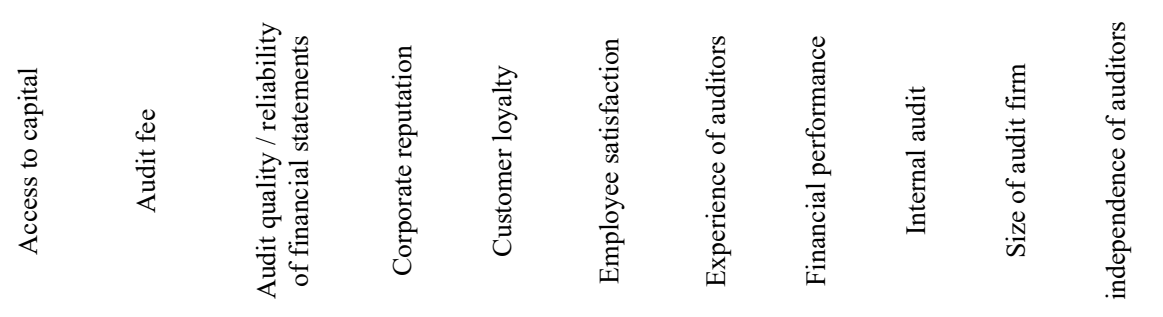

\begin{tabular}{|c|c|c|c|c|c|c|c|c|c|c|c|}
\hline Access to capital & 0.897 & & & & & & & & & & \\
\hline Audit fee & 0.371 & 0.813 & & & & & & & & & \\
\hline Audit quality / reliability of financial statements & 0.282 & 0.029 & 0.769 & & & & & & & & \\
\hline Corporate reputation & 0.387 & 0.254 & 0.258 & 0.835 & & & & & & & \\
\hline Customer loyalty & 0.285 & 0.146 & 0.170 & 0.236 & 0.879 & & & & & & \\
\hline Employee satisfaction & 0.251 & 0.177 & 0.206 & 0.221 & 0.161 & 0.796 & & & & & \\
\hline Experience of auditors & 0.221 & 0.295 & 0.036 & 0.261 & 0.192 & 0.222 & 0.821 & & & & \\
\hline Financial performance & 0.358 & 0.382 & 0.392 & 0.314 & 0.139 & 0.282 & 0.390 & 0.806 & & & \\
\hline Internal audit & 0.230 & 0.009 & 0.021 & 0.270 & 0.193 & 0.240 & 0.029 & 0.232 & 0.799 & & \\
\hline Size of audit firm & 0.368 & 0.271 & 0.023 & 0.231 & 0.169 & 0.221 & 0.007 & 0.390 & 0.022 & 0.833 & \\
\hline independence of auditors & 0.265 & 0.025 & 0.043 & 0.274 & 0.172 & 0.196 & 0.036 & 0.395 & 0.049 & 0.036 & 0.793 \\
\hline
\end{tabular}

Table 3

The results of model fit

\begin{tabular}{lcc}
\hline & Saturated Model & Estimated Model \\
\hline SRMR & 0.062 & 0.068 \\
d_ULS & 0.221 & 0.124 \\
d_G1 & 0.438 & 0.462 \\
d_G2 & 0.468 & 0.465 \\
Chi-Square & $1,363.556$ & $1,378.832$ \\
NFI & 0.888 & 0.856 \\
\hline
\end{tabular}

Coefficients such as: $\mathrm{SRMR}=0.068<0.082$, d_ULS $=22.1 \%<95 \%$, d_G1 $=43.8 \%<95 \%$, d_G $2=46.2 \%<95 \%$ all met requirements (goodness of model fit). According to Henseler et al. (2009, $\left.{ }^{2} 012,2015,2016\right)$, the results in Table 3 show that the research model is suitable with the research data and satisfies the conditions for performing the next analysis.

\section{Table 4}

The results of $\mathrm{R}$ Square

\begin{tabular}{lll}
\hline & R Square & R Square Adjusted \\
\hline Financial performance & 0.358 & 0.355 \\
Audit quality & 0.452 & 0.451 \\
\hline
\end{tabular}

The results in Table 4 show that the data showing the variables in the research model explain more than $35 \%$ of the variation of the dependent variable - financial efficiency (Henseler \& Chin, 2010). According to Hair et al. (2012), the $\mathrm{R}^{2}$ coefficient is from 0 to 1 , the closer to 1 , the more accurate the research model. Henseler et al. (2015), arguing that $\mathrm{R}^{2}$ : strong (0.67), average (0.33) and weak (0.19). Next, we went to test the research hypotheses. The testing results are given in Table 5. The hypothesis test results show that most of the hypotheses are satisfied, only two hypotheses are the impact of capital access on financial efficiency and employee satisfaction on financial efficiency without statistical significance. The hypothesis test results are extracted from Smart PLS software as stated in Table 5. From the results of the hypothesis test, the audit quality / reliability of financial statements has an average impact on customer loyalty. In developed countries, the truthfulness of all disclosed information, including financial information published in financial statements, is of great interest to customers and affects their loyalty to the business brands and products they're consuming. However, in the context of a developing country like Vietnam, especially in tourism businesses, the financial information is almost only affected at the average level with the impact level of 0.170 at the meaningful level $1 \%\left(\mathrm{P}_{-}\right.$value $\left.=0.001\right)$. This is easy to understand, the loyalty of customers in the tourism industry is mainly based on the service and attraction of the destination but less dependent on the quality of published financial information. Following the audit quality / reliability of information on the financial statements has a very strong impact on the capital access of tourism and travel businesses at the impact level of 0.482 with a $1 \%$ significance level $\left(\mathrm{P}_{-}\right.$value $\left.=0.000\right)$. 


\section{Table 5}

Path Coefficients

Mean, STDEV, T-Values, P-Values

\begin{tabular}{|c|c|c|c|c|c|}
\hline & $\begin{array}{l}\text { Original } \\
\text { Sample } \\
(\mathrm{O})\end{array}$ & $\begin{array}{c}\text { Sample } \\
\text { Mean } \\
\text { (M) }\end{array}$ & $\begin{array}{c}\text { Standard } \\
\text { Deviation } \\
(\text { STDEV) }\end{array}$ & $\begin{array}{l}\text { T Statistics } \\
(|\mathrm{O} / \mathrm{STDEV}|)\end{array}$ & P Values \\
\hline Access to capital $\rightarrow$ Financial performance & 0.028 & 0.027 & 0.074 & 0.379 & 0.705 \\
\hline Audit quality / reliability of financial statements $\rightarrow$ Access to capital & 0.482 & 0.484 & 0.047 & 10.192 & 0.000 \\
\hline Audit quality / reliability of financial statements $\rightarrow$ Audit fee & 1.029 & 1.029 & 0.016 & 63.237 & 0.000 \\
\hline Audit quality / reliability of financial statements $\rightarrow$ Corporate reputation & 0.458 & 0.461 & 0.044 & 10.342 & 0.000 \\
\hline Audit quality / reliability of financial statements $\rightarrow$ Customer loyalty & 0.170 & 0.174 & 0.051 & 3.313 & 0.001 \\
\hline Audit quality / reliability of financial statements $\rightarrow$ Employee satisfaction & 0.206 & 0.208 & 0.053 & 3.860 & 0.000 \\
\hline Audit quality / reliability of financial statements $\rightarrow$ Experience of auditors & 1.036 & 1.036 & 0.009 & 115.240 & 0.000 \\
\hline Audit quality / reliability of financial statements $\rightarrow$ Financial performance & 0.162 & 0.161 & 0.064 & 2.533 & 0.012 \\
\hline Audit quality / reliability of financial statements $\rightarrow$ Internal audit & 1.021 & 1.022 & 0.010 & 97.730 & 0.000 \\
\hline Audit quality / reliability of financial statements $\rightarrow$ Size of audit firm & 1.023 & 1.023 & 0.013 & 78.935 & 0.000 \\
\hline Audit quality / reliability of financial statements $\rightarrow$ independence of auditors & 1.043 & 1.042 & 0.009 & 120.522 & 0.000 \\
\hline Corporate reputation $\rightarrow$ Financial performance & 0.361 & 0.366 & 0.063 & 5.759 & 0.000 \\
\hline Customer loyalty $\rightarrow$ Financial performance & 0.184 & 0.179 & 0.050 & 3.657 & 0.000 \\
\hline Employee satisfaction $\rightarrow$ Financial performance & 0.095 & 0.101 & 0.052 & 1.822 & 0.069 \\
\hline
\end{tabular}

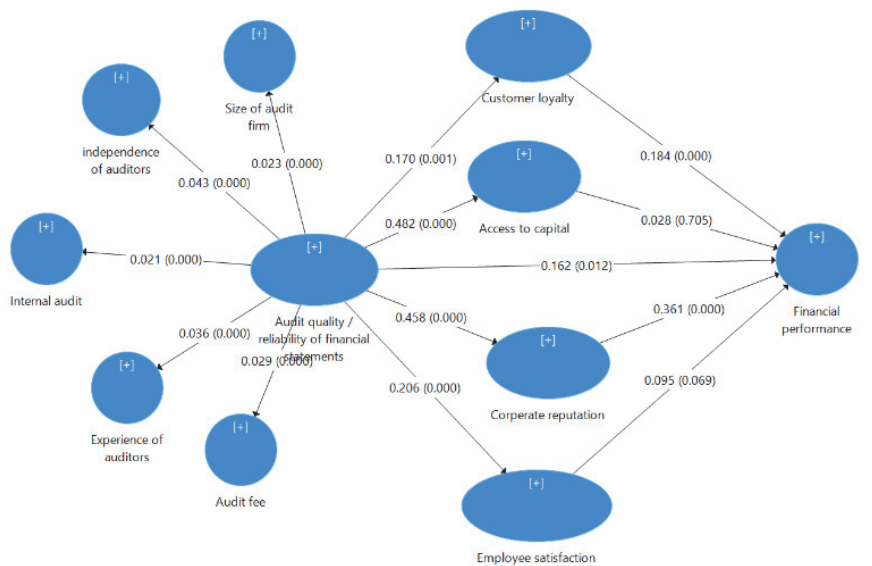

Fig. 3. Results of a hypothesis test (Bootstrap out)

In emerging economies like Vietnam, many market failures exist such as asymmetric information between investors and businesses, between credit institutions (lenders) and businesses, therefore, the audit quality / reliability of information on financial statements plays an extremely important role in raising capital of all types of businesses in general and tourism and tourism businesses in particular. The audit quality / reliability of information on financial statements also has a strong impact on the reputation of tourism and travel businesses at a very large impact level of 0.458 with a $1 \%$ significance level $\left(\mathrm{P} \_\right.$value $=$ 0.000). In Vietnam, tourism and travel companies have recently been in fierce competition for brand, quality and reputation. Companies compete with each other in different ways such as price, service quality, and the incomplete institutional context like Vietnam, but the support of management team, the quality of the audit, as well as the reliability of the information on the financial statements are important. In other developed countries, in the context of Vietnamese tourism and travel businesses, the audit quality / reliability of information on financial statements has a strong impact on the reputation of the business. Finally, workers in travel and tourism businesses are in a service industry, whose income depends entirely on the services they provide, in order to know whether their level of dedication is appropriate. For this reason, the survey results show that the audit quality / reliability of information on financial statements has a moderate impact on employee satisfaction with an impact level of 0.206 at $1 \%$ significance level $\left(\mathrm{P}_{-}\right.$value $\left.=0.000\right)$. According to the research results given in Fig. 2 , we understand that the audit quality / reliability of the information in the financial statements had a direct impact on the financial performance, although the average effect is 0.162 at the $5 \%$ significance level $\left(\mathrm{P}_{-}\right.$value $\left.=0.012\right)$. This means that the relationship between the quality of the audit / the reliability of the information on the financial statements is not a full mediate relationship. Next, the impact of intermediary variables on the financial performance of travel and tourism businesses is as follows: Firstly, customer loyalty has a moderate impact to financial efficiency with an impact level of 0.184 at the $1 \%$ significance level $\left(\mathrm{P}_{\text {_value }}=0.000\right)$. For the travel and tourism service business enterprises, the satisfaction, loyalty and return of tourists are very important because this directly affects the existence and development of the business. However, in the context of a poor country like Vietnam, customer loyalty has not much impact on the financial performance of businesses. Besides, the reputation of the business has a very strong impact on financial efficiency at the impact level of 0.361 with a $1 \%$ significance level $\left(P_{-}\right.$value $\left.=0.000\right)$. For any business, the reputation 
of the business is very important. Finally, access to capital and employee satisfaction do not have a statistically significant relationship with the financial performance of travel and tourism businesses. Tourism and travel businesses are mainly small and medium-sized businesses. In addition, tourism and travel businesses have a small workforce and do not require high professional qualifications. Therefore, employee satisfaction did not statistically significant impact on financial performance.

\section{Conclusion, limitations and future research}

From the above research results, the quality of the audit has had a great impact on improving the financial performance as well as the financial efficiency of tourism and travel businesses in Vietnam. Therefore, travel businesses need to focus on improving the quality of audits including internal and independent audits.

\section{Limitations and future research}

Our research was conducted within a year with the enthusiastic and responsible participation of the members of the study team. However, the research team still has some limitations as follows:

- Firstly: Our research is only conducted for tourism and travel businesses in Vietnam, so it is not representative of the entire Vietnamese economy.

- Second: The study does not distinguish between the different sectors in the tourism sector to see whether there is a difference in the impact of audit quality on financial performance.

- Third: Our study does not pay attention to the socio-economic geographic characteristics of the provinces in the research sample affecting the relationship between audit quality / audit tools on financial performance.

- Fourth: The research on measurement quality of audits was o based on the assessment of the auditing firm, so it lacks the objectivity of the auditing firm and its stakeholders.

From the limitations that the research team has identified by itself, we strongly propose future research directions as follows:

- First: Future studies should research in a broader scope to ensure the representative of the whole economy.

- Second: Future studies should assess the impact and control of the demographic variables of the leaders in these enterprises, as well as the controlling the role of regional socio-economic characteristics and specific business activities of each industry.

- Third: Future studies can use secondary data sources in combination with primary data sources and correlation testing to get more objective results and avoid bias of survey method.

\section{References}

Afza, T., \& Nazir, M.S. (2014). Audit quality and firm value: A case of Pakistan. Research Journal of Applied Science, Engineering and Technology, 7(9), 1803-1810.

Akinbuli, S. F. (2010). The effect of audit expectation gap on the work of auditors, the profession and users of financial information. The Nigerian Accountant, 43(4), 37-47.

Almajali, A. Y., Alamro, S. A., \& Al-Soub, Y. Z. (2012). Factors affecting the financial performance of Jordanian insurance companies listed at Amman Stock Exchange. Journal of Management Research, 4(2), 266.

Aras, G., Aybars, A., \& Kutlu, O. (2010). Managing corporate performance. International Journal of Productivity and Performance Management, 59(3), 229-254.

Bowman, E. H., \& Haire, M. (1975). A strategic posture toward corporate social responsibility. California Management Review, 18(2), 49-58.

Chen, R., \& Wong, K. A. (2004). The determinants of financial health of Asian insurance companies. Journal of risk and insurance, 71(3), 469-499.

Che-Ahmad, A., \& Houghton, K. A. (1996). Audit fee premiums of big eight firms: Evidence from the market for medium-size UK auditees. Journal of International Accounting, Auditing and Taxation, 5(1), 53-72.

Clarkson, P. M., Li, Y., Richardson, G. D., \& Vasvari, F. P. (2008). Revisiting the relation between environmental performance and environmental disclosure: An empirical analysis. Accounting, Organizations and Society, 33(4-5), $303-327$.

Craswell, A., Stokes, D. J., \& Laughton, J. (2002). Auditor independence and fee dependence. Journal of Accounting and Economics, 33(2), 253-275.

DeAngelo, L. E. (1981). Auditor independence, 'low balling', and disclosure regulation. Journal of Accounting and Economics, 3(2), 113-127.

Deshpande, P. V., \& Jones, K. V. (2001). An audit of RCP guidelines on DMSA scanning after urinary tract infection. Archives of disease in childhood, 84(4), 324-327. 
Farouk, M. A., \& Hassan, S. U. (2014). Impact of audit quality and financial performance of quoted cement firms in Nigeria. International Journal of Accounting and Taxation, 2(2), 1-22.

Fooladi, M., \& Shukor, Z. A. (2012, December). Board of directors, audit quality and firm performance: evidence from Malaysia. In National Research \& Innovation Conference for Graduate Students in Social Sciences (pp. 7-9).

Francis, J. R. (1984). The effect of audit firm size on audit prices: A study of the Australian market. Journal of Accounting and Economics, 6(2), 133-151.

Francis, J. R., \& Simon, D. T. (1987). A test of audit pricing in the small-client segment of the US audit market. Accounting Review, 145-157.

Francis, J. R. (2004). What do we know about audit quality?. The British Accounting Review, 36(4), $345-368$.

Gul, F. A., Wu, D., \& Yang, Z. (2013). Do individual auditors affect audit quality? Evidence from archival data. The Accounting Review, 88(6), 1993-2023.

Hayes, R., Dassen Roger, Schilder, A., Wallage, P. (2005). Principles of Auditing. An Introduction to International Standards of Auditing. 2nd ed, Harlow: Pearson Prentice Hall.

Jensen, M. C., \& Meckling, W. (1976). Theory of the firm: managerial behavior, agency costs and ownership structure En: Journal of Finance Economics, 3.

Jusoh, M. A., Ahmad, A., \& Omar, B. (2013). Managerial ownership, audit quality and firm performance in Malaysian. International Journal of Arts and Commerce, 2(10), 45-58.

Khurana, I. K., \& Raman, K. K. (2004). Litigation risk and the financial reporting credibility of Big 4 versus non-Big 4 audits: Evidence from Anglo-American countries. The Accounting Review, 79(2), 473-495.

Kinney, W. R., Martin, R. D., \& Martin, R. (1994). Does auditing reduce bias in financial reporting? A review of audit-related adjustment studies. Auditing, 13(1), 149-156.

Lily Marlina, A.M., \& dan Takiah, M.I. (2003) Kualiti Pelaporan Maklumat Syarikatsyarikat di Bursa Saham Kuala Lumpur, Jurnal Pengurusan, 22, 27-45.

McGuire, J. B., Sundgren, A., \& Schneeweis, T. (1988). Corporate social responsibility and firm financial performance. Academy of Management Journal, 31(4), 854-872.

Michelman, J. E., Gorman, V., \& Trompeter, G. M. (2011). Accounting Fraud at CIT Computer Leasing Group, Inc. Issues in Accounting Education, 26(3), 569-591.

Mohd-Mohid, R., \& Takiah, M. I. (2004). Audit Fee Premiums from Brand Name. Industry Specialization and Industry Leadership: A Study of The Post Big, 6, 1-24.

Pearce, N. J., Perkins, W. T., Westgate, J. A., Gorton, M. P., Jackson, S. E., Neal, C. R., \& Chenery, S. P. (1997). A compilation of new and published major and trace element data for NIST SRM 610 and NIST SRM 612 glass reference materials. Geostandards newsletter, 21(1), 115-144.

Phan, T., Lai, L., Le, T., \& Tran, D. (2020). The impact of audit quality on performance of enterprises listed on Hanoi Stock Exchange. Management Science Letters, 10(1), 217-224.

Ritchie, J. R. B., \& Crouch, G. I. (2000, June). Are destination stars born or made: Must a competitive destination have star genes. In Lights, Camera, Action-31st Annual Conference Proceedings.

Russo, M. V., \& Fouts, P. A. (1997). A resource-based perspective on corporate environmental performance and profitability. Academy of Management Journal, 40(3), 534-559.

Santos, J. B., \& Brito, L. A. L. (2012). Toward a subjective measurement model for firm performance. BAR-Brazilian Administration Review, 9(SPE), 95-117.

Stanwick, S. D., \& Stanwick, P. A. (2000). The relationship between environmental disclosures and financial performance: an empirical study of US firms. Eco-Management and Auditing: The Journal of Corporate Environmental Management, 7(4), 155-164.

Teoh, H. Y. (1990). The Advertising of External Audit. Managerial Auditing Journal.

Walker, M., \& Tsalta, A. (2001). Corporate financial disclosure and analyst forecasting activity: preliminary evidence for the UK. Certified Accountants Educational Trust.

Watts, R. L., \& Zimmerman, J. L. (1983). Agency problems, auditing, and the theory of the firm: Some evidence. The Journal of Law and Economics, 26(3), 613-633.

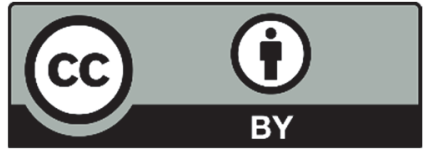

(C) 2020 by the authors; licensee Growing Science, Canada. This is an open access article distributed under the terms and conditions of the Creative Commons Attribution (CC-BY) license (http://creativecommons.org/licenses/by/4.0/). 